\title{
A new technology solution to the problem of increasing the capacity of cathodes in lithium-ion cells of the $\mathrm{LiLaAl} / \mathrm{LiClO}_{4} / \mathrm{LiLaMnOF}\left(\mathrm{C}_{60}\right)_{n}$ system
}

\author{
E.S. Guseva,* R.K. Frantsev and S.S. Popova
}

"Machines and apparatuses for chemical, oil-and-gas and food industries" Department, Engels technology institute named after Yu.A. Gagarin, pl. Svobody, 17, Engels, 413100

Russian Federation

*E-mail: kett-lada@mail.ru

\section{Abstract}

Creating new effective ways to increase the capacity characteristics of cathode materials for lithium-ion cells (LIC) and increasing their electrical conductivity and chemical resistance to electrolyte exposure by modifying their composition and structure are crucial in the electrochemical materials science. A study on the possibility of improving the electric characteristics of a $\mathrm{MnO}_{2}$ electrode by treatment using the method of cathodic intercalation of lanthanum from an aprotic organic salt solution containing fullerene $\mathrm{C}_{60}$ and fluoride ions made it possible to identify the involvement of each of the components in the formation of new $\mathrm{Li}_{x} \mathrm{La}_{y} \mathrm{MnO}_{2-\delta} \mathrm{F}_{\delta}\left(\mathrm{C}_{60}\right)_{n}$ phases whose structure facilitates the subsequent process of lithium intercalation-deintercalation and accumulation in the bulk of the cathode material, and to develop process recommendations in case modification is performed in potentiostatic mode: a $0.5 \mathrm{~mol} / 1$ solution of lanthanum sulfonate $\mathrm{La}\left(\mathrm{OHC}_{6} \mathrm{H}_{4} \mathrm{COO}\right)_{3}$ in a mixture of propylene carbonate and dimethoxyethane PC + DME $(1: 1)$ containing $\mathrm{C}_{60}(28.1 \mathrm{~g} / \mathrm{l})$ and $\mathrm{LiF}(14 \mathrm{~g} / \mathrm{l})$, potential $E_{\mathrm{c}}=-2.9 \mathrm{~V}$ (relative to $\mathrm{SSCE}$ ), duration $30 \mathrm{~min}$. Subsequent intercalationdeintercalation of lithium was performed in $0.8 \mathrm{M}$ solution of $\mathrm{LiClO}_{4}$ in $\mathrm{PC}+\mathrm{DME}(1: 1)$ at the same potential. The inhibition of corrosion (anodic dissolution) during the chargedischarge process was hindered by the presence of lanthanum cations intercalated in the LiAl anode structure. Lanthanum cations promote an increase in inhibition of anodic processes and an increase in the number of cycles upon electrode cycling. The component composition of $\mathrm{La}_{\mathrm{y}} \mathrm{Mn}_{1-y} \mathrm{O}_{2-\delta} \mathrm{F}_{\delta}\left(\mathrm{C}_{60}\right)_{n}$ and $\mathrm{Li}_{x} \mathrm{La}_{y} \mathrm{Mn}_{1-y} \mathrm{O}_{2-\delta} \mathrm{F}_{\delta}\left(\mathrm{C}_{60}\right)_{n}$ electrodes was determined. The regularities that we found make it possible to adjust the electrochemical activity of the cathode, increase its chemical stability, charge durability, and cycleability, and suggest it for use in lithium-ion cells (LIC). The prototype tests performed on the LIC system $\mathrm{LiLaAl} / \mathrm{LiClO}_{4} / \mathrm{Li}_{x} \mathrm{La}_{\mathrm{y}} \mathrm{Mn}_{1-y} \mathrm{O}_{2-\delta} \mathrm{F}_{\delta}\left(\mathrm{C}_{60}\right)_{n}$ showed an increase in the capacity by $7-8 \%$ compared to the non-modified $\mathrm{MnO}_{2}$ "cathode".

Keywords: manganese dioxide, lithium fluoride, fullerene, lithium-ion cell, cathodic intercalation, electrochemical intercalation, modification. 


\section{Introduction}

The production of lithium-ion cells (LIC) is among the most rapidly developing areas in the field of self-contained power sources used in military devices, medicine, instrument engineering, and special-purpose apparatus engineering [1-4]. However, as the requirements for energy intensity and power grow tighter, the long recharging time and the high self-cost hinder the growth of LIC production [5-8]. Therefore, the search for ways of modifying their chemical resistance to electrolyte exposure, charge stability and, hence, an increase in capacity characteristics is one of the most important areas of electrochemical materials science concerning LIC. This problem can be solved using the method of cathodic intercalation resulting in processes at the interface that cause structural changes in the cathode material [14-16].

The purpose of this work was to modify the composition, structure and properties of the material produced in the industry for the manufacture of $\mathrm{MnO}_{2}$ cathodes by cathodic implantation of lanthanum salts containing fullerene and fluoride ions in aprotic organic solutions, and to identify the advantages of the modified cathode material in terms of capacity characteristics compared to the traditional $\mathrm{Li} / \mathrm{MnO}_{2}$ system.

\section{Experimental}

Objects studied: 1) a manganese dioxide electrode containing $\mathrm{MnO}_{2}$ (90\%), furnace technical conductive carbon P 267 E TU 38.11574-86 (5\%), fluoroplastic suspension F-4D in the form of plates with a working surface area of $\left.2.0 \mathrm{~cm}^{2}(5 \%) ; 2\right) \mathrm{a} \mathrm{La}_{y} \mathrm{Mn}_{1-y} \mathrm{O}_{2}$ electrode prepared from an electrode with the composition (1) modified by cathodic treatment in a solution of lanthanum salicylate in dimethylformamide; (3) an electrode with the composition $\mathrm{La}_{y} \mathrm{Mn}_{1-y} \mathrm{O}_{2}$ (2) additionally modified in a lithium perchlorate solution, $0.8 \mathrm{M} \mathrm{LiClO}_{4}$ in a mixture of propylene carbonate (PC) with dimethoxyethane (DME); (4) a $\mathrm{La}_{y} \mathrm{Mn}_{1-y} \mathrm{O}_{2-\delta} \mathrm{F}_{\delta}\left(\mathrm{C}_{60}\right)_{n}$ electrode was prepared by cathodic treatment of $\mathrm{MnO}_{2}$ (1) in a dimethylformamide solution of lanthanum salicylate $(0.5 \mathrm{~mol} / \mathrm{l})$ containing $\mathrm{LiF}(14 \mathrm{~g} / \mathrm{l})$ and fullerene $\mathrm{C}_{60}(28 \mathrm{~g} / \mathrm{l})$ at $E_{\mathrm{c}}=-2.9 \mathrm{~V}, t_{\mathrm{ct}}=0.5 \mathrm{~h}$ [17-20]. The subsequent treatment at $-2.9 \mathrm{~V}$ in the lithium salt solution was performed for $1 \mathrm{~h}$. Before each experiment, the surface of the starting $\mathrm{MnO}_{2}$ electrode (1) was cleaned with alcohol and air-dried for 5 min. Prior to lithium intercalation, all the $\mathrm{MnO}_{2}, \mathrm{La}_{y} \mathrm{Mn}_{1-y} \mathrm{O}_{2}, \mathrm{La}_{y} \mathrm{Mn}_{1-y} \mathrm{O}_{2}\left(\mathrm{C}_{60}\right)_{n}$ and $\mathrm{La}_{y} \mathrm{Mn}_{1-y} \mathrm{O}_{2-\delta} \mathrm{F}_{\delta}\left(\mathrm{C}_{60}\right)_{n}$ electrodes were rinsed in $0.8 \mathrm{M}$ solution of $\mathrm{LiClO}_{4}$ in a $\mathrm{PC}+\mathrm{DME}$ mixture (1:1). The potentials of $\mathrm{Li}_{x} \mathrm{MnO}_{2}, \quad \mathrm{La}_{y} \mathrm{Mn}_{1-y} \mathrm{O}_{2}, \quad \mathrm{La}_{y} \mathrm{Mn}_{1-y} \mathrm{O}_{2}\left(\mathrm{C}_{60}\right)_{n}$ and $\mathrm{La}_{y} \mathrm{Mn}_{1-y} \mathrm{O}_{2-\delta} \mathrm{F}_{\delta}\left(\mathrm{C}_{60}\right)_{n}$ before and after the lithiation were controlled using a non-aqueous silver/silver chloride electrode (SSCE) in $0.8 \mathrm{M}$ solution of $\mathrm{LiClO}_{4}$ in a $\mathrm{PC}+\mathrm{DME}$ mixture $(1: 1 \mathrm{v} / \mathrm{v})$ saturated with $\mathrm{LiCl}$ (or $\mathrm{LaCl}_{3}$, accordingly). The potential of the $\mathrm{Li} / \mathrm{Li}^{+}$ electrode relative to SCCE is $-2.85 \mathrm{~V}$. An aluminum foil electrode $(99.99 \%$, A99, GOST 11069-74) $100 \mu \mathrm{m}$ thick pretreated for $1 \mathrm{~h}$ at $\mathrm{E}=-2.9 \mathrm{~V}$ in $0.8 \mathrm{M} \mathrm{LiClO}_{4}$ in a PC + DME mixture (1:1) was used as the auxiliary electrode $\left(S=1 \mathrm{~cm}^{2}\right)$. To increase the chemical resistance and mechanical strength of a $\mathrm{LiAl}$ anode, aluminum was pretreated in the same 
lanthanum salt solution that can be regarded as a specific corrosion inhibitor of the LiLaAl anode material. Cycling of electrodes made in this way was carried out according to a mixed technique of lithium intercalation (charging): in potentiostatic mode at $\mathrm{E}_{\mathrm{c}}=-2.9 \mathrm{~V}$ for 1 hour, while the discharge of the $\mathrm{La}_{y} \mathrm{Mn}_{1-y} \mathrm{O}_{2-\delta} \mathrm{F}_{\delta}\left(\mathrm{C}_{60}\right)_{n}$ electrode was performed in galvanostatic mode at a current density of $0.05 \mathrm{~mA} / \mathrm{cm}^{2}$ to $E_{\mathrm{eq}}=0 \mathrm{~V}$. A JSM-5900LV (JEOL) scanning electron microscope was used to study the composition and properties of the resulting phases. The elementary compositions in the structure of the cathodes synthesized $\left(\mathrm{La}_{y} \mathrm{Mn}_{1-y} \mathrm{O}_{2}, \mathrm{La}_{y} \mathrm{Mn}_{1-y} \mathrm{O}_{2}\left(\mathrm{C}_{60}\right)_{n}, \mathrm{La}_{y} \mathrm{Mn}_{1-y} \mathrm{O}_{2-\delta} \mathrm{F}_{\delta}\right.$, and $\left.\mathrm{La}_{y} \mathrm{Mn}_{1-y} \mathrm{O}_{2-\delta} \mathrm{F}_{\delta}\left(\mathrm{C}_{60}\right)_{n}\right)$ in atomic percent are shown in Table 1.

\section{Results and Discussion}

Comparison of the composition of $\mathrm{La}_{y} \mathrm{Mn}_{1-y} \mathrm{O}_{2}, \mathrm{La}_{y} \mathrm{Mn}_{1-y} \mathrm{O}_{2}\left(\mathrm{C}_{60}\right)_{n}, \mathrm{La}_{y} \mathrm{Mn}_{1-y} \mathrm{O}_{2-\delta} \mathrm{F}_{\delta}$, and $\mathrm{La}_{y} \mathrm{Mn}_{1-y} \mathrm{O}_{2-\delta} \mathrm{F}_{\delta}\left(\mathrm{C}_{60}\right)_{n}$ electrodes with the original manganese dioxide electrode made it possible to identify the changes in the atomic ratios of elements that are due to chemical reactions and the formation of new phases that are actively involved in the intercalationdeintercalation of lithium (Table 1).

Table 1. Elemental composition of the synthesized electrodes.

\begin{tabular}{cccccc}
\hline Electrode material & $\mathbf{C}(\boldsymbol{\%})$ & $\mathbf{M n}(\boldsymbol{\%})$ & $\mathbf{O}(\boldsymbol{\%})$ & $\mathbf{L a}(\boldsymbol{\%})$ & $\mathbf{F}(\boldsymbol{\%})$ \\
\hline $\mathrm{MnO}_{2}$ & 3.44 & 79.28 & 17.28 & - & - \\
$\mathrm{La}_{y} \mathrm{MnO}_{2}$ & 3.54 & 75.58 & 20.38 & 0.5 & - \\
$\mathrm{La}_{y} \mathrm{Mn}_{1-y} \mathrm{O}_{2}\left(\mathrm{C}_{60}\right)_{n}$ & 9.05 & 68.14 & 18.00 & 4.80 & - \\
$\mathrm{La}_{y} \mathrm{Mn}_{1-y} \mathrm{O}_{2-\delta} \mathrm{F}_{\delta}$ & 5.13 & 62.09 & 16.23 & 5.1 & 11.45 \\
$\mathrm{La}_{y} \mathrm{Mn}_{1-y} \mathrm{O}_{2-\delta} \mathrm{F}_{\delta}\left(\mathrm{C}_{60}\right)_{n}$ & 20.28 & 19.22 & 15.51 & 23.8 & 21.18 \\
\hline
\end{tabular}

According to the data presented in Table 2, upon cycling in galvanostatic mode, the $\mathrm{Li}_{x} \mathrm{La}_{y} \mathrm{Mn}_{1-y} \mathrm{O}_{2}, \mathrm{Li}_{x} \mathrm{La}_{y} \mathrm{Mn}_{1-y} \mathrm{O}_{2}\left(\mathrm{C}_{60}\right)_{n}, \mathrm{Li}_{x} \mathrm{La}_{y} \mathrm{Mn}_{1-y} \mathrm{O}_{2-\delta} \mathrm{F}_{\delta}$, and $\mathrm{Li}_{x} \mathrm{La}_{y} \mathrm{Mn}_{1-y} \mathrm{O}_{2-\delta} \mathrm{F}_{\delta}\left(\mathrm{C}_{60}\right)_{n}$ electrodes showed an increase in current load, capacity with respect to lithium and lanthanum, and reversibility.

If the modifying additives are introduced together, redistribution of the amounts of intercalated lithium and lanthanum ions, fullerene, and fluoride ions is accompanied by a synergistic effect, which clearly indicates the formation of new phases that facilitate the lithium intercalation-deintercalation process and participation of all the components $\left(\mathrm{MnO}_{2}, \mathrm{La}^{3+}, \mathrm{F}^{-}, \mathrm{C}_{60}\right)$ in increasing the capacity of electrodes with respect to lithium. This phase may consist of fullerene $\mathrm{C}_{60}$ fluoride complexes. They allow a larger amount of $\mathrm{La}^{3+}$ and $\mathrm{Li}^{+}$cations to be intercalated and enhance their binding with the $\mathrm{MnO}_{2}$ structure and, accordingly, the chemical resistance to the electrolyte exposure. 
Table 2. Specific charge/discharge capacity as a function of the cycle number in galvanostatic mode $\left(i_{\text {dis }}=\right.$ $\left.0.05 \mathrm{~mA} / \mathrm{cm}^{2}\right)$; the final discharge potential is $E_{\mathrm{dis}}=-(0.2 \pm 0.1) \mathrm{V}$.

\begin{tabular}{cccc}
\hline Electrode & Cycle number $\boldsymbol{N}$ & $\begin{array}{c}\text { Specific discharge } \\
\text { capacity } \boldsymbol{Q}_{\text {diss }}, \mathbf{m A h} / \mathbf{g}\end{array}$ & $\begin{array}{c}\text { Capacity } \\
\text { efficiency, } \%\end{array}$ \\
\hline $\mathrm{Li}_{x} \mathrm{MnO}_{2}$ & 1 & 218.7 & 91.1 \\
$\left(E_{\text {currentless }}=-0.38 \mathrm{~V}\right)$ & 50 & 39.3 & 16.4 \\
& 100 & 20.0 & 8.3 \\
\hline $\mathrm{Li}_{x} \mathrm{La}_{y} \mathrm{Mn}_{1-y} \mathrm{O}_{2}$ & 1 & 173.0 & 72.1 \\
$\left(E_{\text {currentless }}=-0.72 \mathrm{~V}\right)$ & 50 & 70.5 & 29.4 \\
\hline $\mathrm{Li}_{x} \mathrm{La}_{y} \mathrm{Mn}_{1-y} \mathrm{O}_{2-\sigma}\left(\mathrm{C}_{60}\right)_{n}$ & 100 & 28.6 & 11.9 \\
$\left(E_{\text {currentless }}=-0.25 \mathrm{~V}\right)$ & 1 & 182.5 & 82 \\
\hline & 50 & 78.3 & 32.6 \\
$\mathrm{Li}_{x} \mathrm{La}_{y} \mathrm{Mn}_{1-y} \mathrm{O}_{2-\sigma} \mathrm{F}_{\sigma}$ & 100 & 32 & 13.8 \\
$\left(E_{\text {currentless }}=-0.4 \mathrm{~V}\right)$ & 1 & 176 & 31.6 \\
\hline $\mathrm{Li}_{x} \mathrm{La}_{\mathbf{y}} \mathrm{Mn}_{1-y} \mathrm{O}_{2-\sigma} \mathrm{F}_{\sigma}\left(\mathrm{C}_{60}\right)_{n}$ & 50 & 76 & 13.8 \\
$\left(E_{\text {currentless }=-0.42 \mathrm{~V})}\right.$ & 100 & 33.2 & 75.2 \\
\hline
\end{tabular}

Our data [17-20] show the prospects of the proposed method for modifying the $\mathrm{MnO}_{2}$ electrodes, making it possible to simplify the technology for synthesizing a cathode material at the preliminary preparation stage, and also to improve its economic and energy indicators that allow it to be implemented into industrial production.

The established regularities of the electrochemical activity of the $\mathrm{MnO}_{2}$ electrode, increasing its charge durability and cycleability make it possible to suggest the cathode material synthesized for use in lithium-ion batteries. The prototype tests performed on the $\mathrm{LIC}$ of the $\mathrm{LiLaAl} / \mathrm{LiClO}_{4} / \mathrm{Li}_{x} \mathrm{La}_{y} \mathrm{Mn}_{1-y} \mathrm{O}_{2-\sigma} \mathrm{F}_{\delta}\left(\mathrm{C}_{60}\right)_{n}$ system showed an increase in capacity by $7-8 \%$ compared to the non-modified $\mathrm{MnO}_{2}$ "cathode".

\section{Conclusions}

Thus, analysis of the results of cycling of $\mathrm{MnO}_{2}$ and $\mathrm{Li}_{x} \mathrm{La}_{y} \mathrm{Mn}_{1-y} \mathrm{O}_{2-\delta} \mathrm{F}_{\delta}\left(\mathrm{C}_{60}\right)_{n}, \mathrm{La}_{\mathrm{y}} \mathrm{Mn}_{1-y} \mathrm{O}_{2}$, $\mathrm{Li}_{x} \mathrm{La}_{\mathrm{y}} \mathrm{Mn}_{1-y} \mathrm{O}_{2}\left(\mathrm{C}_{60}\right)_{n}$ and $\mathrm{Li}_{x} \mathrm{La}_{\mathrm{y}} \mathrm{Mn}_{1-y} \mathrm{O}_{2-\delta} \mathrm{F}_{\delta}$ electrodes synthesized in a $0.8 \mathrm{M} \mathrm{LiClO}_{4}$ solution in $\mathrm{PC}+\mathrm{DME}$ in potentiodynamic and galvanostatic modes shows that the interactions of fullerene with lanthanum (or its analogs) and lithium cations and simultaneously with fluoride ions provide a synergistic effect that enhances the 
electrochemical characteristics. The data obtained not only provide a new significant contribution to the theory of cathodic intercalation but also allow us to suggest new methodological approaches and, using the developed electrochemical system $\mathrm{LiLaAl}_{\text {ox }} / \mathrm{Li}_{x} \mathrm{La}_{y} \mathrm{Mn}_{1-y} \mathrm{O}_{2-\delta} \mathrm{F}_{\delta}\left(\mathrm{C}_{60}\right)_{n}$, expand variant predictions of modernization of development of LIC, taking into account all the identified factors that affect the properties of the cathode material and provide the possibility of increasing the capacity characteristics of LIC due to a decrease in volume changes in the structure of the cathode and a reduction in the loss of capacity upon cycling. The practical recommendations can find use in the development of new electrode materials on matrix basis for current sources that are reversible with respect to alkali metal ions and REE.

\section{References}

1. A.Yu. Tsivadze, T.L. and A.M. Skundin, Prot. Met. Phys. Chem. Surf., 2013, 49, no. 2, 145 (in Russian). doi: 10.7868/S0044185613020083

2. A.G. Morachevskij, A.A. Popovich and A.I. Demidov, Application of lithium, its alloys and compounds for electrochemical power sources (dedicated to the 25th anniversary of beginning the production of lithium-ion cells), Scientific and technical bulletin of St. Petersburg State Polytechnic University, Metallurgy and materials science, 2016, 1, 65-79 (in Russian). doi: 10.5862/JEST.238.7

3. V. Elser and R.C. Haddon, Icosahedral $\mathrm{C}_{60}$ : an aromatic molecule with a vanishingly small ring current magnetic susceptibility, Nature, 2002, 325, 792-794. doi: $10.1038 / 325792 \mathrm{a} 0$

4. E. Barsoukov and J.R. Macdonald, Impedance spectroscope theory, experiment, and application, Hoboken, John Wiley and Sons, Inc., 2005.

5. P. Lam and R. Yazami, Physical characteristics and rate performance of $\left(\mathrm{CF}_{\mathrm{x}}\right)_{\mathrm{x}}$ $(0.33<\mathrm{x}<0.66)$ in lithium batteries, Power Sources, 2006, 153, 354-359.

6. T. Nakajima, Carbon-fluorine compounds as battery materials, J. Fluorine Chem., 1999, 100, no. 1-2, 57-61. doi: 10.1016/S0022-1139(99)00219-5

7. A.S. Claye, J.E. Fischer, C.B. Huffman, A.G. Rinzler and R.E. Smalley, Solid-State Electrochemistry of the Li Single Wall Carbon Nanotube System. J. Electrochem. Soc., 2000, 147, no. 8, 2845-2852. doi: $10.1149 / 1.1393615$

8. H. Wang, H. Huang and S.L. Wunder, Novel Microporous Poly(vinylidene fluoride) Blend Electrolytes for Lithium-Ion Batteries, J. Electrochem. Soc., 2000, 147, no. 8, 2853-2861. doi: 10.1149/1.1393616

9. M. Zhao, S. Kariuki, H.D. Dewald, F.R. Lemke, R.J. Staniewicz, E.J. Plichta and R.A. Marsh, Electrochemical Stability of Copper in Lithium-Ion Battery Electrolytes, J. Electrochem. Soc., 2000, 147, no. 8, 2874-2879. DOI: 10.1149/1.1393619.

10. Huang C.-K., Sakamoto J.S., Wolfenstine J., Surampudi S. The Limits of LowTemperature Performance of Li-Ion Cells. J. Electrochem. Soc., 2000, 147, no. 8, 2893-2896. DOI: 10.1149/1.1393621. 
11. M. Balasubramanian, X. Sun, X.Q. Yang and J. McBreen, X-Ray Absorption Studies of a High-Rate $\mathrm{LiNi}_{0.85} \mathrm{Co}_{0.15} \mathrm{O}_{2}$ Cathode Material, J. Electrochem. Soc., 2000, 147, no. 8, 2903-2909. doi: 10.1149/1.1393624

12. W.B. Gu and C.Y. Wang, Thermal-Electrochemical Modeling of Battery Systems, $J$. Electrochem. Soc., 2000, 147, no. 8, 2910-2922. doi: 10.1149/1.1393625

13. J. Whitacre, R. Yazami, A. Hamwi, A. Hamwi, M.C.Smart, W. Bennett, G.K. Surya Prakash, T. Miller and R. Bugg, Low operational temperature Li-CFx batteries using cathodes containing sub-fluorinated graphitic materials. J. Power Sources, 2006, 160, no.1, 577-584. doi: 10.1016/j.jpowsour.2006.01.045

14. J.P. Meyers, M. Doyle, R.M. Darling and J. Newman, The Impedance Response of a Porous Electrode Composed of Intercalation Particles, J. Electrochem. Soc., 2000, 147, no. 8, 2930-2940. doi: 10.1149/1.1393627

15. A.A. Potanin, Solid-state chemical power source based on an ionic conductor such as lanthanum trifluoride, Rossiiskii khimicheskii zhurnal, 2001, XLV, no. 5-6, 59-63 (in Russian).

16. S.A. Fateev, T.L. Kulova and A.M. Skundin, Lithium fluorocarbon power sources for implantable pacemakers, Electroktrokhimicheskaya energetika, 2005, 5, no. 2, 106108 (in Russian).

17. E.S. Guseva, M.Yu. Kurenkova, K.R. Kasimov and S.S. Popova, Fluorocarbon cathodes for lithium power sources, Elektrokhimicheckaya energetika, 2005, 5, no. 4, 263-265 (in Russian).

18. E.S. Guseva, R.K. Frantsev and S.S. Popova, Electrochemical intercalation of the $\mathrm{MnO}_{2}$ electrode in aprotic organic solutions of rare-earth elements salts, Izv. vys. ucheb. zaved. Khimiya i khimicheckaya tekhnologiya, 2011, 54, no. 5, 138-139 (in Russian).

19. E.S. Guseva, S.S. Popova and R.K. Frantsev, Influence of the rare-earth metal nature on the kinetics of electrochemical processes on $\mathrm{MnO}_{2}$-electrodes in aprotic organic solutions, Elektrokhimicheckaya energetika, 2011, 11, no. 2, 108-111 (in Russian).

20. E.S. Guseva and S.S. Popova, Electrochemical behavior of $\mathrm{MnO}_{2}$ electrode in aprotic organic solutions of salts of lanthanum and its analogues (rare earth elements), Elektrokhimicheckaya energetika, 2017, 17, no. 1, 19-28 (in Russian). 